\title{
AOR
}

Selected Papers of \#AolR2020:

The 22nd Annual Conference of the

Association of Internet Researchers

Virtual Event / 13-16 Oct 2021

\section{THE ANATOMY OF DIGITAL CLOUT(CHASING): VISIBILITY AND RELATIONAL LABOR AMONG DIY HIP-HOP MUSICIANS ON CHICAGO'S SOUTH SIDE}

\author{
Jabari M. Evans, MSW PhD \\ University of South Carolina

\section{Background and Introduction}

Social media, streaming services and e-commerce platforms have drastically changed the artistic labor practices of musical artists as they now must move between and within platforms to self-promote themselves to professionalize and sustain their careers (Haynes \& Marshall, 2018). Social media support the strength of fan communities by providing launching pads for these burgeoning artists to speak directly to fans of their music, build personal relationships with them and let them share in their creative process (Baym, 2012). These relationships can go beyond simple "friending" to direct messaging and holding live chats that lead to other kinds of interpersonal contact. A rapidly professionalizing and monetizing wave of diverse, multicultural, previously amateur musicians from around the world have harnessed these platforms to incubate their own media brands, engage in content innovation, and cultivate often massive, transnational, and cross-cultural fan communities (Baym, 2018). Much research on various forms of Influencers on social media has focused on self-curation (Abidin, 2014; Marwick, 2015; Wissinger, 2015), follower-engagement (Abidin, 2015), authenticity (Hopkins and Thomas, 2011) and advertorial disclosure (Ots and Abidin, 2015), as well as ordinary users as 'promotional apparatus' for brands (Carah and Shaul, 2016) and as participants in electronic word of mouth (Erkan, 2015).

All of these factors have provided a unique and precarious opportunity to emerging HipHop artists, who often are seeking to find a wider audience often while nestled in communities of digital disadvantage (Watkins, 2019). In being a Hip-Hop musician, representing one's place authentically while connecting to the wider culture is an

Evans, J.M. (2021, October). The Anatomy of Digital Clout(chasing): Black Aesthetics, Online Visibility and Relational Labor Among DIY Hip-Hop Musicians on Chicago's South Side. Paper presented at AolR 2021: The 22nd Annual Conference of the Association of Internet Researchers. Philadelphia, PA, USA: AolR. Retrieved from http://spir.aoir.org. 
essential yet complicated task (Forman, 2002). However, now with the "always on" nature of impression management on social media (Duffy, 2017), Hip-Hop musicians are now routinely tasked with keeping constant connection between multiple platforms to affirm their authenticity and promote their craft to an audience of global Hip-Hop fans who are inundated with content (Stuart, 2020). Even still, having levels of audience engagement through social media has become the new measure of success for music artists, as talent scouts and record label executives now use these metrics as a way to identify the next stars.

Against this backdrop, this article empirically examines social media strategy from the perspective of successful Do-It-Yourself (DIY) Hip-Hop artists. Drawing from ethnographic fieldwork and several interviews with prominent members of Chicago's Hip-Hop scene, this study examines the role of social media as an economic resource in their artistic labor. Bridging traditional theories of urban sociology with emerging new media scholarship, I argue that the Hip-Hop artists use subcultural capital through savvy engagement with social media to amass a type of urban cultural influence, which they deem clout. For purposes of this article, I re-define the term as digital clout since clout was a term that was heavily used by our interviewees to refer to the way they measured their influence on social media according to counts of likes, views, re-posts and followers.

As Hip-Hop's origins are from America's low-income urban communities of color (Perry, 2004) clout is pursued as aspirational labor (Duffy, 2017) with the hopes of gaining fame and financial rewards. Given this context, I suggest that digital clout is driven by visibility labor (Abidin, 2016) that claims authentic Blackness through scripts of toughness, sexual prowess and conspicuous consumption of luxury goods. I also argue that Black youth use Hip-Hop music to harness the power of clout to articulate a sense of place and a resistance to that place's public reputation on their own terms and in their own words. Ultimately, this clout allowed them to compete, collaborate, connect within the larger Hip-Hop community of cultural producers and build a creative economy for their micro-celebrity. Through constant engagement on social media this clout can be used to sell podcasts, blogs, merchandise, books and fashion. This type of clout also can garner influencer work for corporate brands.

I initially focus on Hip-Hop's penchant for corralling - friend-anchored social media campaigns, wherein self-promotional posts published simultaneously across and within platforms by an artist's support group manipulated algorithmic recommender systems and amplified the circulation for an artist's content. Next, I focus on co-signs and how gaining visibility among industry tastemakers in Hip-Hop has transformed but remains vital through social media. Finally, I speak about the practice of capping, and the aspirational labor of exaggerating one's social position to project street authenticity and material wealth to an online audience. Ultimately, I argue that these practices collectively suggest that Hip-Hop artists deploy a style of self-presentation in their artistic labor that requires novel impression management skills through the simultaneous navigation of poverty and violent risk from many of its participants. To conclude, I discuss the implications of these arguments for understanding how social, familial, economic, cultural, political factors shape youth digital participation and diverse forms of online affiliation and participation. 


\section{References}

Abidin, C. (2015). Communicative intimacies: Influencers and perceived interconnectedness. Ada, 8, 1-16.

Abidin, C. (2016a). Visibility labour: Engaging with Influencers' fashion brands and\# OOTD advertorial campaigns on Instagram. Media International Australia, 161(1), 86100.

Abidin, C. (2016b). Please subscribe!: Influencers, social media, and the commodification of everyday life (Doctoral dissertation, University of Western Australia).

Abidin, C., \& Ots, M. (2016). Influencers tell all. Unravelling Authenticity and Credibility in a Brand Scandal, 153-161.

Baym, N. K. (2012). Fans or friends?: Seeing social media audiences as musicians do. Participations, 9(2), 286-316.

Baym, N. K. (2018). Playing to the crowd: Musicians, audiences, and the intimate work of connection (Vol. 14). NYU Press.

Carah, N., \& Shaul, M. (2016). Brands and Instagram: Point, tap, swipe, glance. Mobile Media \& Communication, 4(1), 69-84.

Duffy, B. E. (2017). (Not) getting paid to do what you love: Gender, social media, and aspirational work. Yale University Press.

Erkan, I. (2015). Electronic word of mouth on Instagram: Customers' engagements with brands in different sectors. International Journal of Management, Accounting and Economics, 2(12), 1435-1444.

Forman, M. (2002). The'hood comes first: Race, space, and place in rap and hip-hop. Wesleyan University Press.

Haynes, J., \& Marshall, L. (2018). Beats and tweets: Social media in the careers of independent musicians. New Media \& Society, 20(5), 1973-1993.

Marwick, A. E. (2015). Instafame: Luxury selfies in the attention economy. Public culture, $27(1(75)), 137-160$.

Perry, I. (2004). Prophets of the hood: Politics and poetics in hip hop. Duke University Press.

Stuart, F. (2020). Ballad of the bullet: Gangs, drill music, and the power of online infamy. Princeton University Press. 
Watkins, C. S. (2019). Don't Knock the Hustle: Young Creatives, Tech Ingenuity, and the Making of a New Innovation Economy. Beacon Press.

Wissinger, E. (2015). This year's model: Fashion, media, and the making of glamour. NYU Press. 